\title{
REVIEW
}

\section{Structural bases of vasopressin/oxytocin receptor function}

\author{
C Barberis, B Mouillac and T Durroux \\ INSERM U 469, CCIPE, 141 rue de la Cardonille, 34094 Montpellier Cedex 05, France \\ (Requests for offprints should be addressed to C Barberis)
}

\section{Introduction}

The neurohypophyseal hormones vasopressin and oxytocin are two closely related nonapeptides, synthesized mainly by the magnocellular neurons of the hypothalamus. Their peptide sequences differ only in the amino acids at positions 3 and 8 , but, for both hormones, the formation of a disulfide bond between Cys residues at the 1 and 6 positions results in a peptide constituted of a 6 amino acid cyclic part and a 3 amino acid C-terminal part. Both peptides exert various hormonal effects. Circulating oxytocin is mostly known for its ability to elicit the contraction of uterine smooth muscle at term and that of myoepithelial cells that surround the alveoli of the mammary gland during lactation. The main endocrine functions of arginine vasopressin (AVP) are the facilitation of water reabsorption by the kidney and the contraction of smooth muscle cells in arteries. AVP released in the portal blood in the median eminence acts as a potent secretagogue of adrenocorticotropin. In addition, it has become clear that vasopressin and oxytocin, besides mediating well-documented functions at the periphery, are also critically involved in numerous central processes including higher cognitive functions such as memory and learning (see Barberis \& Tribollet 1996 for review).

Vasopressin and oxytocin were the first biologically active peptides to be synthesized. This achievement, by $\mathrm{Du}$ Vigneaud and coworkers, 40 years ago, ushered in the modern era of peptide chemistry. During the subsequent decades, many structural analogues of the neurohypophyseal hormones have been synthesized and pharmacologically characterized (Manning \& Sawyer 1993).

Peripheral vasopressin and oxytocin receptors have been classified on the basis of both the second messenger system coupled to the receptors and the affinity of a series of vasopressin and oxytocin analogues with enhanced selectivity for a certain receptor type. These classification criteria have led to the distinction of V1a vasopressin (liver, smooth muscle cells from blood vessels, and most peripheral tissues expressing vasopressin receptors), V1b vasopressin (adenohypophysis), V2 vasopressin (kidney) and oxytocin (uterus, mammary gland) receptors (Jard et al. 1988). To date central receptors have been identified as being of the vasopressin V1a and oxytocin subtypes. Moreover, a great number of molecular probes have been developed, including agonists and antagonists, and radiolabelled, fluorescent or photosensitive ligands. These make this receptor family a good model with which to study structure-function relationships.

Today, the four different receptor subtypes have been cloned in mammals, lower vertebrates and invertebrates. Molecular cloning studies have renewed interest in these neurohormone receptors. Vasopressin V1b receptor mRNA has been detected in peripheral tissues (kidney, thymus, heart, lung, spleen, uterus and breast) and numerous areas of the brain in the rat (Lolait et al. 1995), and this receptor subtype has also been characterized in rat adrenal (Grazzini et al. 1996). These studies suggest that the vasopressin $\mathrm{V} 1 \mathrm{~b}$ receptor may serve additional and unknown functions in the brain and at the periphery. The primary focus of this review is to summarize recent studies that have led to novel insights into the molecular bases of vasopressin and oxytocin receptor functions.

\section{General structural features}

Molecular cloning of this family has confirmed that vasopressin/oxytocin receptor subtypes are members of the G-protein-coupled receptor (GPCR) superfamily, consisting of seven hydrophobic transmembranes $\alpha$-helices joined by alternating intracellular and extracellular loops, an extracellular $\mathrm{N}$-terminal domain, and a cytoplasmic C-terminal domain (Fig. 1). They display a high degree of sequence identity, showing about 102 invariant amino acids among the 370-420 amino acids in the human receptors (Fig. 2). In addition, vasopressin/oxytocin receptors display the structural hallmarks characteristic of most GPCRs: glycosylation on Asn residues present in the extracellular domains, a disulfide bridge between two highly conserved Cys residues in the second and third extracellular domains, and two relatively well-conserved Cys residues within the C-terminal receptor domain, which have been shown to be palmitoylated in other GPCRs (Ovchinnikov et al. 1988, O'Dowd et al. 1989). Whereas the disulfide bond appears to be required for the 


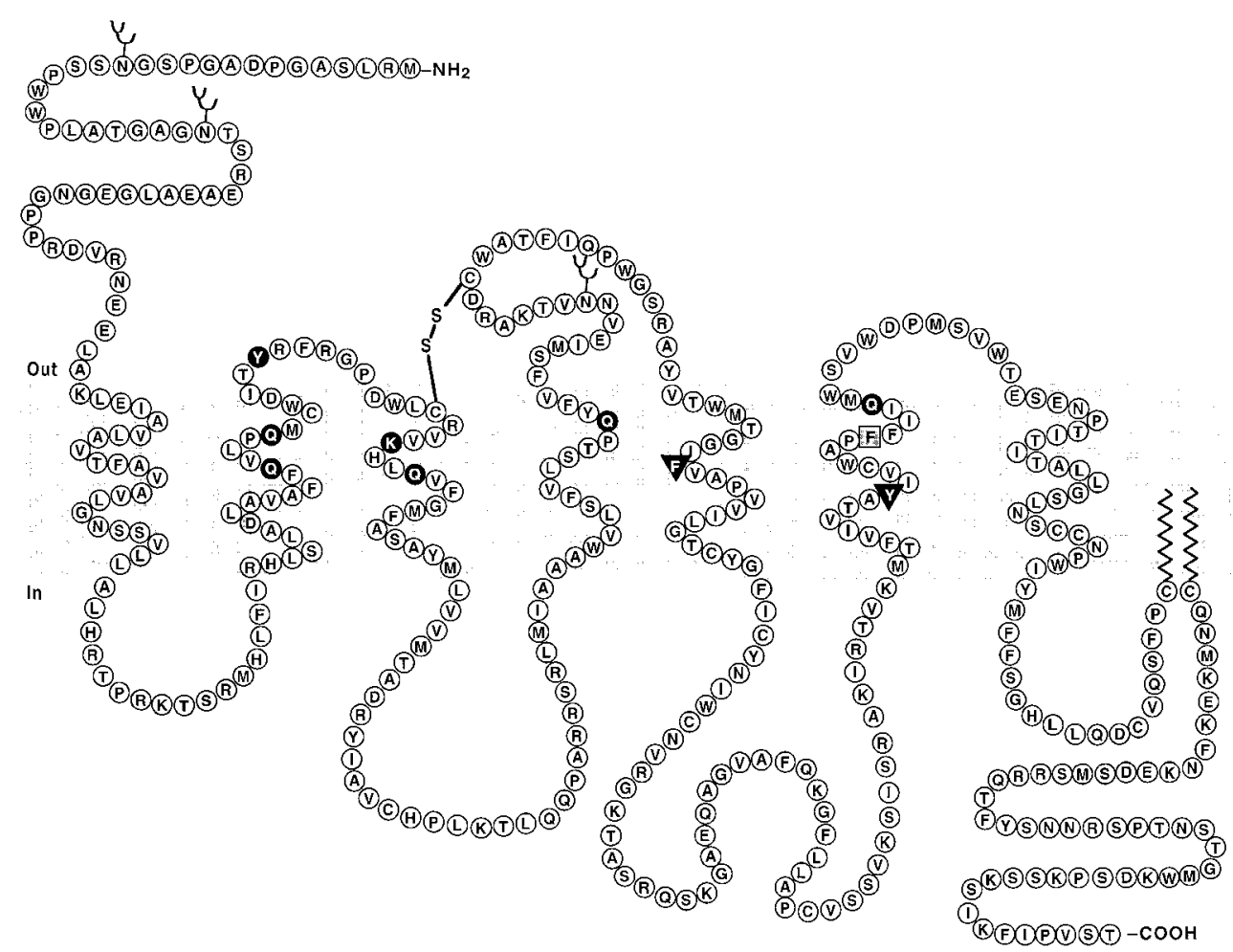

Figure 1 Transmembrane topology of the human vasopressin V1a receptor showing functionally important residues. Amino acids highlighted in black circles are critically involved in agonist binding (see text for details); that in the grey square is possibly involved in antagonist binding; that in the grey circle is a conserved amino acid involved in activation of the receptor; those in black triangles modulate the process of receptor activation in oxytocin receptor (see text for details). Potential glycosylation (on Asn 14, 27 and 196) and palmitoylation (on Cys 365 and 366) sites are also indicated.

correct folding of vasopressin/oxytocin receptors, the potential functional relevance of the glycosylation and palmitoylation of vasopressin/oxytocin receptors remains to be established. $\mathrm{Cys}^{124}$ and $\mathrm{Cys}^{205}$ in the rat V1a receptor are possibly involved in the tertiary structure of the receptor, as suggested by the fact that $\left[{ }^{3} \mathrm{H}\right] \mathrm{AVP}$ binding to V1a receptors of rat liver is altered by the presence of free sulfhydryl group alkylating agents such as $N$-ethylmaleimide (Gopalakrishnan et al. 1988). The same is true for human platelet V1a receptors and bovine and porcine V2 receptors (Pavo \& Fahrenholz 1990, Thibonnier et al. 1993). In the pig V2 lysine vasopressin receptor expressed in the LLCPK1 cell line, it has been reported that glycosylation has a minor role in the transport and function of receptor (Jans et al. 1992). More recently, Innamorati et al. (1996) have shown that the functional properties (including hormone binding, coupling to the as subunit of the $G$ proteins, desensitization and internalization) of the non-glycosylated human V2 vasopressin receptor are unaltered. Similarly, in the human V2 vasopressin receptor, palmitoylation does not seem to be important for receptor binding and signaling (Sadeghi et al. 1995, 1997).

\section{Structural bases of ligand binding}

Agonists

Consistent with findings obtained with the adrenoceptors (Dohlman et al. 1991) and muscarinic receptors (Wess 1996), ligand binding to vasopressin receptors is predicted to occur in a pocket formed by the ring-like arrangement of the seven transmembrane domains (Mouillac et al. 1995). In view of the great number of residues that appear to be involved in vasopressin binding, it may be speculated that the hormone-receptor complex is characterized by an intricate network of hydrogen bond interactions, rather than by a few well-defined points of contact (Fig. 3). The conclusions drawn from the mutagenesis experiments are consistent with three-dimensional molecular modeling studies of vasopressin and vasotocin receptors, which suggest that the agonist-binding site is located in a narrow cleft delimited by several transmembrane (TM) domains (primarily TM II-VII), about $15 \AA$ away from the extracellular surface.

Mutagenesis studies have shown that replacement of the conserved Gln residues in the rat V1a receptor situated in TM II, III, IV and VI and a Lys residue localized in TM 

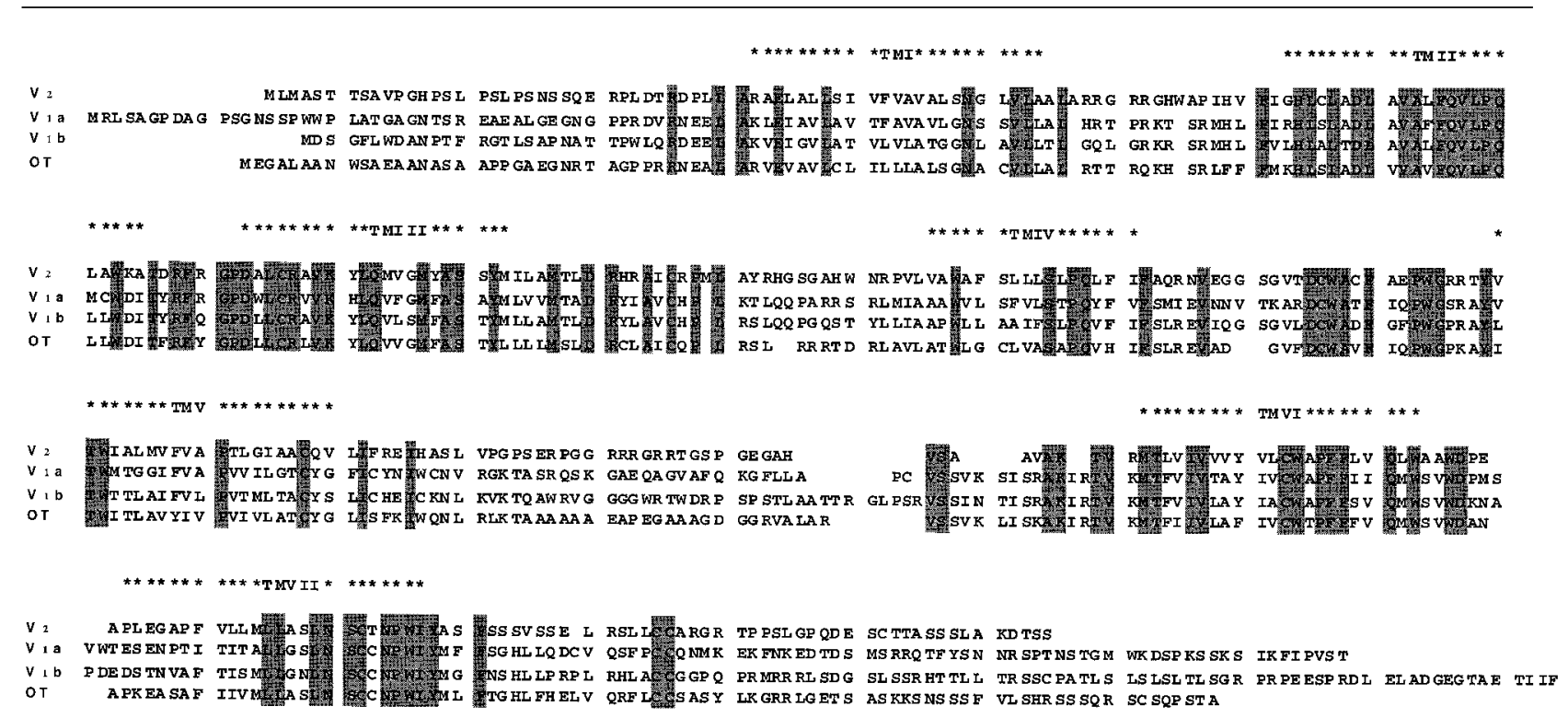

Figure 2 Primary sequence comparisons between human vasopressin/oxytocin receptors. Gaps have been introduced to maximize sequence identities. Asterisks denote predicted transmembrane regions I-VII. V2, amino acid sequence of the human V2 receptor (Birnbaumer et al. 1992); V1a, amino acid sequence of the human V1a receptor (Thibonnier et al. 1994); V1b, amino acid sequence of the human V1b receptor (de Keyser et al. 1994, Sugimoto et al. 1994); OT, amino acid sequence of the human oxytocin receptor (Kimura et al. 1992).

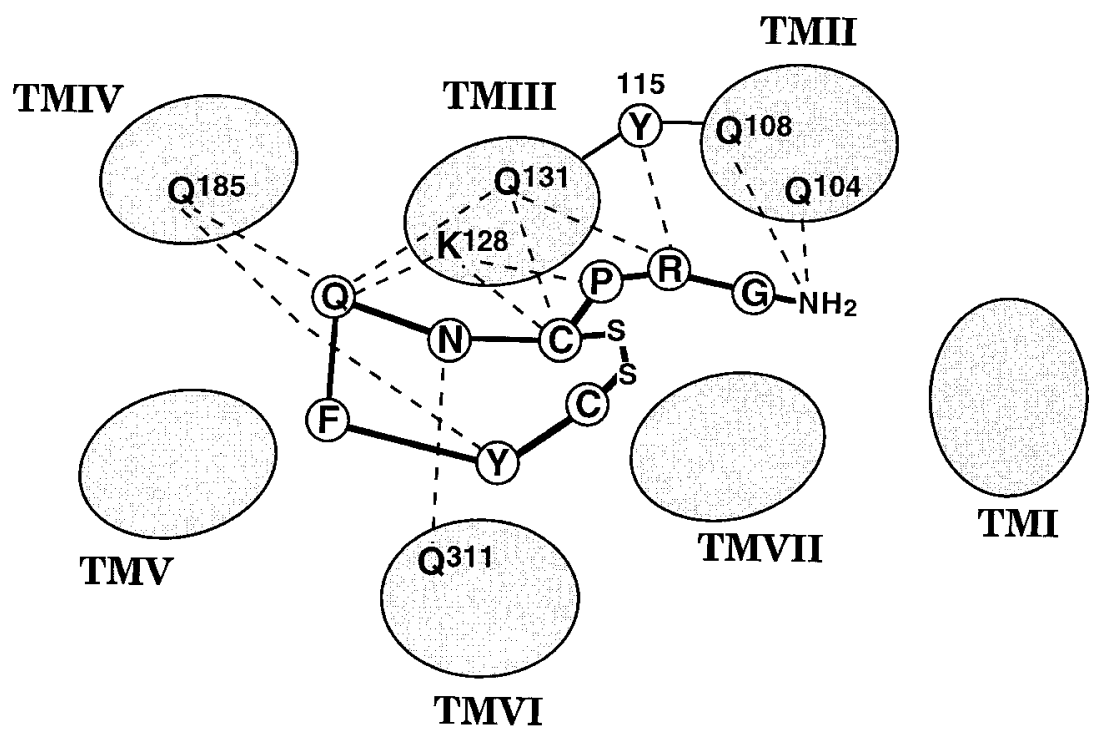

Figure 3 Schematic representation of the interaction of vasopressin with the membranespanning domains of the vasopressin $\mathrm{V} 1 \mathrm{a}$ receptor, viewed from the surface of the plasma membrane. Amino acids shown to be involved in this interaction are indicated (see text).

III (Figs 1 and 2) by Ala residues results in receptors that have a decreased affinity for the vasopressin receptor agonists, vasopressin, oxytocin and $\left[\mathrm{Phe}^{2}, \mathrm{Orn}^{8}\right]$-vasotocin (Mouillac et al. 1995). Interestingly, these residues are highly conserved in all the vasopressin and oxytocin receptors. It was therefore proposed that the agonistbinding pocket is common to all the different subtypes of this receptor family (Mouillac et al. 1995). Indeed, more recently, mutational analyses of the fish $\left[\mathrm{Arg}^{8}\right]$-vasotocin receptor have shown that substitution of Lys $^{101}$ (the residue homologous to $\mathrm{Lys}^{128}$ in TM III of the rat V1a receptor) by Met or Ala resulted in a reduction in vasotocin binding. Substitution of $\mathrm{Gln}^{104}$ (the residue homologous to $\operatorname{Gln}^{131}$ in rat V1a receptor) by a Leu 
residue resulted in a loss of vasotocin binding (Hausmann et al. 1996). It should be noted that this Gln in AVP/ oxytocin receptors corresponds, in sequence alignment, to the Asp on TM III, which is highly conserved in cationic neurotransmitter receptors and has a key role in their binding. Interestingly, replacement of $\mathrm{Thr}^{223}$ in the rat V1a receptor with Ala residue had no effect on vasopressin binding, suggesting that this Thr residue, which corresponds to a Ser residue that is conserved in catecholamine receptors and contributes to catecholamine binding, is not important for correct recognition of vasopressin.

In addition to residues situated in the transmembrane regions, residues located in the extracellular domains also interact with the hormones. This notion is strongly supported by photoaffinity labeling of the first extracellular loop of bovine V2, using an analogue of lysine vasopressin that has a photoactivatable group on the lateral chain of residue 8 (Kojro et al. 1993). In addition, mutagenesis studies have shown that replacement of $\mathrm{Tyr}^{115}$ (in the first extracellular loop of the rat V1a receptor; Figs 1 and 3) with Asp or Phe, the amino acids naturally occurring in the human V2 and oxytocin receptors, results in a potent increase in V2 or oxytocin agonist-binding affinities (Chini et al. 1995). Similar results have also been obtained with the bovine V2 receptor (Ufer et al. 1995). On the basis of these studies, primary sequence analyses and studies of the structure-activity relationships of other neuropeptides and their receptors, the corresponding amino acid in the first extracellular loop was proposed to have a homologous role in conferring affinity and selectivity. This would seem to be particularly true in the case of angiotensin, cholecystokinin, neuropeptide $\mathrm{Y}$ and neurokinin receptors (Trumpp-Kallmeyer et al. 1995).

Other strategies have been used to locate the agonistbinding domains. Chimeric constructs have been made. On the basis of the exchange of extracellular domains between the pig V2 receptor and oxytocin receptor, it has been proposed that the three extracellular loops are important (Postina et al. 1996). Similarly, chimeric constructs encoding parts of the white sucker fish $\left[\mathrm{Arg}^{8}\right]$ vasotocin receptor and parts of the isotocin receptor have shown that the $\mathrm{N}$-terminus and a region spanning the second extracellular loop and its flanking transmembrane segments contribute to the affinity of the $\left[\mathrm{Arg}^{8}\right]$-vasotocin receptor (Hausmann et al. 1996).

Naturally occurring mutations of the human V2 receptors that are responsible for the X-linked nephrogenic diabetes insipidus have also been used to analyze further the structural bases of these receptors. In the human V2 receptor, the natural mutation of $\mathrm{Arg}^{113}$, situated next to the Cys that is involved in a disulfide bridge, to $\operatorname{Trp}^{113}$ significantly reduces receptor expression in transfected cells, receptor-ligand binding affinity and Gs coupling, to such an extent that kidneys challenged either by dehydration or by infusion of 1-deamino[D$\mathrm{Arg}^{8}$ ]VP were unable to produce concentrated urine, thus displaying a complete nephrogenic diabetes insipidus (Bichet et al. 1993, Birnbaumer et al. 1994). A similar reduction in binding affinity and inability to concentrate the urine is found in association with another mutation: deletion of $\mathrm{Arg}^{202}$ situated in the second extracellular loop of the human V2 receptor (Ala et al. 1998).

Another approach to the study of hormone-receptor interactions involves the use of small synthetic peptides that mimick the sequence of the supposed active region of the receptor. This approach has been used in the case of the vasopressin receptor: a 12 amino acid synthetic peptide of the first extracellular loop of the V1a vasopressin receptor inhibited both the binding of agonist and antagonist radioligands to this receptor and the vasopressin-stimulated glycogen phosphorylase activity in isolated rat hepatocytes (Howl \& Wheatley 1996). One 25 amino acid synthetic peptide of the second extracellular loop of the V1a vasopressin receptor, with an additional Cys residue at the C-terminal end, also inhibited radioligand binding and AVP-induced accumulation of inositol phosphate(Mendre et al. 1997). These studies may indicate that the extracellular receptor surface facilitates the initial 'capture' of both peptide and non-peptide ligands.

\section{Antagonists}

Whereas some progress has been made in elucidating the structural determinants underlying vasopressin/oxytocin receptor agonist binding, the receptor domains involved in the binding of vasopressin/oxytocin receptor antagonists are only poorly defined. In particular, it remains unclear which vasopressin/oxytocin receptor subsites are recognized by the bulky hydrophobic ring systems or side chains present in virtually all potent peptide cyclic or linear vasopressin/oxytocin receptor antagonists (Manning et al. 1995).

Mutagenesis studies have shown that those mutations affecting agonist-binding affinities have little effect on antagonist-binding affinities, indicating that the receptor subsites involved in the binding of vasopressin/oxytocin receptor antagonists are not those binding the receptor agonists (Mouillac et al. 1995, Postina et al. 1996). However, the Lys ${ }^{128}$ residue in TM III of the rat V1a receptor seems to be involved not only in recognition of vasopressin and arginine vasotocin, but also in the binding of the competitive non-peptide V1a antagonist, SR 49059. Another residue that could be critical for the binding of both agonists and peptide and non-peptide antagonists to the V1a receptor is the conserved $\operatorname{Gln}^{185}$ situated in TM IV.

In order to delineate the receptor domains that contribute to the binding of vasopressin $\mathrm{V} 1 \mathrm{a}$ receptor antagonists, radioiodinated photosensitive ligands have been prepared and used to label covalently the rat V1a receptor (Carnazzi et al. 1994, 1997). Using this ligand, it 
was possible to identify the photolabelled domain of the human V1a receptor also. Combining the photolabelling results with the predictions of molecular modelling studies, it has been suggested that a hydrophobic cluster of aromatic residues situated in transmembrane VI (Fig. 1) may be involved in the binding of peptide antagonists (Phalipou et al. 1997). Another study, using chimeric oxytocin/V2 receptor in which the third extracellular loop plus the upper part of the TM VII were exchanged between both wild-type receptors, has shown that the upper part of the TM VII contributes to the binding of an oxytocin antagonist (Postina et al. 1996).

\section{Domains conferring G protein-coupling selectivity}

Kidney vasopressin V2 receptors have long been known to interact with adenylyl cyclase to generate cAMP intracellularly and to cause the antidiuretic effects of AVP (Orloff \& Handler 1967). This interaction is made possible through the coupling of the receptor with the $\alpha$ s subunit of the $G$ protein. The receptors of the vasopressin V1a type were initially defined as those receptors present in the hepatocytes that mediate the hydrolysis of phosphatidylinositol 4,5-bisphosphate into inositol 1,4,5-trisphosphate and diacylglycerol and cause an increase in cytosolic calcium (Michell et al. 1979). This vasopressin V1a receptor activation involves $G$ proteins of the $\mathrm{Gq} / \mathrm{G} 11$ family, the $\alpha$-subunits of which, upon receptor activation, regulate the activity of the $\beta$-isoforms of phospholipase C. Several studies have demonstrated a variety of signaling pathways associated with the V1a receptor endogenously expressed in tissues or cell lines. These include activation of phospholipases A2, C and D, increase in intracellular calcium and cell acidification through activation of the $\mathrm{Na}^{+} / \mathrm{H}^{+}$exchange (Briley et al. 1994).

Adenohypophysis $\mathrm{V} 1 \mathrm{~b}$ receptors also stimulate phospholipase C. Oxytocin receptors activate phospholipase C and induce an increase in cytosolic $\mathrm{Ca}^{2+}$ concentration, which results in strong contractions of the uterus at term (Mironneau 1976, Marc et al. 1986).

Single amino acids have been found to be important for the activation of this family of receptor. In the rat V1a vasopressin receptor, the functional importance of the conserved Asp ${ }^{97}$ residue in TM II has been confirmed by mutational analysis (Figs 1 and 2) (Mouillac et al. 1995); this has also been observed for many other GPCRs (Savarese \& Fraser 1992). In human oxytocin receptors, it was found that AVP may act either as a complete agonist, as demonstrated by analysis of the electrophysiological response in Xenopus oocytes (Kimura et al. 1994), or as a partial agonist, as demonstrated by measurement of the release of inositol phosphate in various cell lines (CHO, $\mathrm{Ltk}^{-}$, Cos 7; Chini et al. 1996). This latter property was utilized to identify amino acids that have a key role in regulating agonist-oxytocin receptor interactions. It was found that the $\mathrm{Tyr}^{209}$ in the TM V and the $\mathrm{Phe}^{284}$ in the TM VI of the human oxytocin receptor have such a role. Replacement of these two amino acids with the corresponding residues of the V1a receptor (Figs 1 and 2) resulted in mutant receptors, for which the intrinsic activity of oxytocin itself was not significantly altered, whereas that of AVP was dramatically increased (Chini et al. 1996). As aromatic residues are present at these positions in most rhodopsin-like GPCRs, it was proposed that these residues may modulate the process of receptor activation in various members of the GPCR family.

Another highly conserved residue has also been found to have a key role in the vasopressin/oxytocin receptor activation process. As has been shown for the muscarinic M3 receptor (Wess et al. 1993), the conserved Pro 322 situated on TM VII in the human V2 receptor is probably necessary to allow the relative movements within the helical bundle that are required for receptor activation. Two different mutations of the amino acid have been identified in different families suffering from nephrogenic diabetes insipidus, which resulted in a mutant receptor that was severely impaired in its ability to mediate adenylyl cyclase activation (Ala et al. 1998). The mutation $\mathrm{Pro}^{322}$ to $\mathrm{Ser}^{322}$ yielded a mutant receptor that had a decreased binding affinity for the hormone but was still able to stimulate adenylyl cyclase (although to a lesser degree); this mutation gave a mild clinical phenotype. In contrast, the mutated $\mathrm{Pro}^{322}$ to $\mathrm{His}^{322}$ receptor is completely uncoupled in terms of cellular signaling, which is consistent with the phenotype observed in a patient having a complete clinical expression of the disease (Tajima et al. 1996).

As has been shown for many other receptors, the highly conserved triplet Asp-Arg-Tyr (Asp-Arg-His or Asp-ArgCys in human V2 or human oxytocin receptors respectively) located at the $\mathrm{N}$-terminal of the i2 loop is also required for efficient $G$ protein activation (Savarese \& Fraser 1992). In the human V2 receptor, an $\mathrm{Arg}^{137}$ to $\mathrm{His}^{137}$ mutation was found to abolish coupling to $G$ proteins and cause a complete phenotype of nephrogenic diabetes insipidus (Rosenthal et al. 1993).

To study the structural elements interacting with the $G$ proteins responsible for the functional diversity found within the vasopressin receptor family, V1a-V2 hybrid receptors have been created in which distinct intracellular domains were exchanged between both wildtype receptors (Liu \& Wess 1996). Substitution of the V2 receptor i2 loop for the homologous V1a receptor sequence resulted in a mutant receptor that gained the ability to couple efficiently to $\mathrm{Gq} / \mathrm{G} 11$, but retained the ability to couple to Gs. Analogously, replacement of the i3 loop in the V1a receptor with the homologous V2 receptor sequence yielded a hybrid construct that gained efficient coupling to Gs, but was still able to activate Gq/G11 in a fashion similar to the wild-type V1a receptor. These data strongly suggest that the i3 loop of the V2 receptor has a 
key role in correct recognition and activation of Gs, whereas the i2 loop of the $\mathrm{V} 1 \mathrm{a}$ receptor is critically involved in selective activation of Gq/G11.

\section{Conclusions}

In the past 5 years, there has been considerable progress in knowledge of the structures of the vasopressin and oxytocin receptors, and in the development of molecule agonists and peptide and non-peptide antagonists. Initial studies have already provided some information on the structural requirement for ligand binding and selectivity. However, many aspects of vasopressin and oxytocin receptor function remain only poorly understood. Specifically, the nature of the dynamic changes in the receptor proteins that take place in ligand binding and $G$ protein activation are unknown. Undoubtedly, the availability of a high-resolution structure of vasopressin and oxytocin receptors will greatly facilitate the refinement of threedimensional models of these receptors and hence the acquisition of new information on the receptor domains responsible for agonist or antagonist binding and for $G$ protein activation. This understanding of receptor function, at a molecular level, should be of great help in the development of new molecules with high selectivity for the different subtypes of receptors, and thus in the development of new molecules of potential therapeutic interest. The current clinical implications of AVP and oxytocin receptors lie in oxytocin itself, used in the promotion of labor and delivery, in atosiban, an oxytocin antagonist used in the treatment of preterm labour, and in desmopressin, a selective AVP-V2 agonist used in the treatment of diabetes insipidus, in which there is a deficiency of circulating AVP (see Freidinger \& Pettibone 1997 for review). Alternatively, the knowledge of ligand structure-activity and receptor structure-function relationships may help in the future design of specific agonists able to activate mutated V2 receptors responsible for the $\mathrm{X}$-linked nephrogenic diabetes insipidus.

\section{Acknowledgements}

The contribution made by Drs Y Ala, M N Balestre, B Chini, N Cotte, M Hibert, E Mahé, D Morin and S Phalipou to the work originating from the authors' laboratory is gratefully acknowledged. Excellent secretarial assistance was provided by M Chalier and M Passama.

\section{References}

Ala Y, Morin D, Sabatier N, Vargas R, Cotte N, Déchaux M, Antignac C, Arthus MF, Lonergan M, Turner MS, Balestre MN, Alonso G, Hibert M, Barberis C, Hendy GN, Bichet DG \& Jard S
1998 Functional studies of twelve mutant $V_{2}$ vasopressin receptors related to nephrogenic diabetes insipidus: molecular basis of a mild clinical phenotype. Journal of the American Society of Nephrology (In Press).

Barberis C \& Tribollet E 1996 Vasopressin and oxytocin receptors in the central nervous system. Critical Reviews in Neurobiology $\mathbf{1 0}$ 119-154.

Bichet D, Arthus M, Lonergan M, Hendy G, Paradis A, Fujiwara M, Morgan K, Gregory M, Rosenthal W, Didwania A, Antaramian A \& Birnbaumer M 1993 X-linked nephrogenic diabetes insipidus mutations in North America and the Hopewell hypothesis. Journal of Clinical Investigation 92 1262-1268.

Birnbaumer M, Seibold A, Gilbert S, Ishido M, Barberis C, Antaramian A, Brabet P \& Rosenthal W 1992 Molecular cloning of the receptor for human antidiuretic hormone. Nature 357 333-335.

Birnbaumer M, Gilbert S \& Rosenthal W 1994 An extracellular congenital nephrogenic diabetes insipidus mutation of the vasopressin receptor reduces cell surface expression, affinity for ligand, and coupling to the Gs/adenylyl cyclase system. Molecular Endocrinology 8 886-894.

Briley E, Lolait S, Axelrod J \& Felder C 1994 The cloned vasopressin V1a receptor stimulated phospholipase A2, phospholipase C and phospholipase D through activation of receptor-operated calcium channels. Neuropeptides 27 63-74.

Carnazzi E, Aumelas A, Barberis C, Guillon G \& Seyer R 1994 A new series of photoactivatable and iodinatable linear vasopressin antagonists. Journal of Medicinal Chemistry 37 1841-1849.

Carnazzi E, Aumelas A, Phalipou S, Mouillac B, Guillon G, Barberis C \& Seyer R 1997 Efficient photoaffinity labeling of the rat V1a vasopressin receptor using a linear azidopeptidic antagonist. European Journal of Biochemistry 247 906-913.

Chini B, Mouillac B, Ala Y, Balestre MN, Trumpp-Kallmeyer S, Hoflack J, Elands J, Hibert M, Manning M, Jard S \& Barberis C 1995 Tyr 115 is the key residue for determining agonist selectivity in the V1a vasopressin receptor. EMBO Journal 14 2176-2182.

Chini B, Mouillac B, Balestre MN, Trumpp-Kallmeyer S, Hoflack J, Hibert M, Andriolo M, Pupier S, Jard S \& Barberis C 1996 Two aromatic residues regulate the response of the human oxytocin receptor to the partial agonist arginine vasopressin. FEBS Letters 397 201-206.

Dohlman H, Thorner J, Caron M \& Lefkowitz R 1991 Model systems for the study of seven-transmembrane-segment receptors. Annual Review of Biochemistry 60 653-688.

Freidinger RM \& Pettibone DJ 1997 Small molecule ligands for oxytocin and vasopressin receptors. Medicinal Research Reviews 17 $1-16$.

Gopalakrishnan V, McNeill J, Sulakhe P \& Triggle C 1988 Hepatic vasopressin receptor: differential effects of divalent cations, guanine nucleotides, and $\mathrm{N}$-ethyl maleimide on agonist and antagonist interactions with the V1 subtype receptor. Endocrinology 123 922-931.

Grazzini E, Lodboerer AM, Perez-Martin A, Joubert D \& Guillon G 1996 Molecular and functional characterization of V1b vasopressin receptor in rat adrenal medulla. Endocrinology 137 3906-3914.

Hausmann H, Richters A, Kreienkamp H, Meyerhof W, Mattei H, Lederis K, Zwiers H \& Richter D 1996 Mutational analysis and molecular modeling of the nonapeptide hormone binding domains of the $\left[\mathrm{Arg}^{8}\right]$ vasotocin receptor. Proceedings of the National Academy of Sciences of the USA 93 6907-6912.

Howl J \& Wheatley M 1996 Molecular recognition of peptide and non-peptide ligands by the extracellular domains of neurohypophysial hormone receptors. Biochemical Journal 317 577-582.

Innamorati G, Sadeghi H \& Birnbaumer MA 1996 Fully active nonglycosylated V2 vasopressin receptor. Molecular Pharmacology $\mathbf{5 0}$ 467-473.

Jans D, Jans P, Luzius H \& Fahrenholz F 1992 N-glycosylation plays a role in biosynthesis and internalization of the adenylate cyclase 
stimulating vasopressin V2-receptor of LLC-PK1 renal epithelial cells: an effect of concanavalin A on binding and expression. Archives of Biochemistry and Biophysics 294 64-69.

Jard S, Elands J, Schmidt A \& Barberis C 1988 Vasopressin and oxytocin receptors: an overview. In Progress in Endocrinology, pp 1183-1188. Eds H Imura \& K Shizume. Amsterdam: Elsevier.

de Keyser Y, Auzan C, Lenne F, Beldjord C, Thibonnier M, Bertagna X \& Clauser E 1994 Cloning and characterization of the human V3 pituitary vasopressin receptor. FEBS Letters 356 215-220.

Kimura T, Tanizawa O, Mori K, Brownstein M \& Okayama H 1992 Structure and expression of a human oxytocin receptor. Nature 356 526-529.

Kimura T, Makino Y, Saji F, Takemura M, Inoue T, Kikuchi T, Kubota Y, Azuma C, Nobunaga T, Tokugawa Y \& Tanizawa O 1994 Molecular characterization of a cloned human oxytocin receptor. European Journal of Endocrinology 131 385-390.

Kojro E, Eich P, Gimpl G \& Fahrenholz F 1993 Direct identification of an extracellular agonist binding site in the renal V2 vasopressin receptor. Biochemistry 32 13537-13544.

Liu J \& Wess J 1996 Different single receptor domains determine the distinct $G$ protein coupling profiles of members of the vasopressin receptor family. Journal of Biological Chemistry 271 8772-8778.

Lolait S, O'Carroll A, Mahan L, Felder C, Button D, Young III W, Mezey E \& Brownstein M 1995 Extrapituitary expression of the rat V1b vasopressin receptor gene. Proceedings of the National Academy of Sciences of the USA 92 6783-6787.

Manning M \& Sawyer W 1993 Design, synthesis and some uses of receptor-specific agonists and antagonists of vasopressin and oxytocin. Journal of Receptor Research 13 195-214.

Manning M, Cheng L, Stoev S, Sawyer WH, Tribollet E, Barberis C, Wo NC \& Chan WY 1995 Novel potent and selective antagonists and radioiodinated ligands for oxytocin and vasopressin receptors. In Neurohypophysis: Recent Progress of Vasopressin and Oxytocin Research, pp 21-38. Eds T Saito, K Kurokawa \& S Yoshida. Amsterdam: Elsevier.

Marc S, Leiber D \& Harbon S 1986 Carbachol and oxytocin stimulate the generation of inositol phosphates in the guinea pig myometrium. FEBS Letters 201 9-14.

Mendre C, Dufour MN, Le Roux S, Seyer R, Guillou L, Calas B \& Guillon G 1997 Synthetic rat V1a vasopressin receptor fragments interfere with vasopressin binding via specific interaction with the receptor. Journal of Biological Chemistry 272 21027-21036.

Michell RH, Kirk CJ \& Billah MM 1979 Hormonal stimulation of phosphatidylinositol breakdown with particular reference to the hepatic effects of vasopressin. Biochemical Society Transactions 7 861-865.

Mirronneau J 1976 Effects of oxytocin on ionic currents underlying rhythm activity and contraction in uterine smooth muscle. Pflüger's Archives 363 113-116.

Mouillac B, Chini B, Balestre MN, Elands J, Trumpp-Kallmeyer S, Hoflack J, Hibert M, Jard S \& Barberis C 1995 The binding site of neuropeptide vasopressin V1a receptor. Evidence for a major localization within transmembrane regions. Journal of Biological Chemistry $27025771-25777$.

O'Dowd B, Hnatowich M, Caron M, Lefkowitz R \& Bouvier M 1989 Palmitoylation of the human $\beta_{2}$-adrenergic receptor. Mutation of $\mathrm{Cys}^{341}$ in the carboxyl tail leads to an uncoupled nonpalmitoylated form of the receptor. Journal of Biological Chemistry 264 7564-7569.

Orloff J \& Handler J 1967 The role of adenosine $3^{\prime}, 5^{\prime}$-phosphate in the action of antidiuretic hormone. American Journal of Medicine $\mathbf{4 2}$ 757-768.
Ovchinnikov YA, Abdulaev NG \& Bogachuk AS 1988 Two adjacent cysteine residues in the $\mathrm{C}$-terminal cytoplasmic fragment of bovine rhodopsine are palmitoylated. FEBS Letters $2301-5$.

Pavo I \& Fahrenholz F 1990 Differential inactivations of vasopressin receptor subtypes in isolated membranes and intact cells by N-ethylmaleimide. FEBS Letters 272 205-208.

Phalipou S, Cotte N, Carnazzi E, Seyer R, Jard S, Barberis C \& Mouillac B 1997 Mapping peptide-binding domains of the human V1a vasopressin receptor with a photoactivatable linear peptide antagonist. Journal of Biological Chemistry 272 26536-26544.

Postina R, Kojro E \& Fahrenholz F 1996 Separate agonist and peptide antagonist binding sites of the oxytocin receptor defined by their transfer into the V2 vasopressin receptor. Journal of Biological Chemistry 271 31593-31601.

Rosenthal W, Antaramian A, Gilbert S \& Birnbaumer M 1993 Nephrogenic diabetes insipidus: a V2 vasopressin receptor unable to stimulate adenylyl cyclase. Journal of Biological Chemistry 268 13030-13033.

Sadeghi HM, Innamorati G \& Birnbaumer M 1995 Functional properties of mutant V2 receptors. In Neurohypophysis: Recent Progress of Vasopressin and Oxytocin Research, pp 445-451. Eds T Saito, K Kurokawa \& S Yoshida. Amsterdam: Elsevier.

Sadeghi HM, Innamorati G, Dagarag M \& Birnbaumer M 1997 Palmitoylation of the V2 vasopressin receptor. Molecular Pharmacology 52 21-29.

Savarese T \& Fraser C 1992 In vitro mutagenesis and the search for structure-function relationships among $\mathrm{G}$ protein-coupled receptors. Biochemical Journal 283 1-19.

Sugimoto T, Saito M, Mochizuki S, Watanabe Y, Hashimoto S \& Kawashima H 1994 Molecular cloning and functional expression of a cDNA encoding the human V1b vasopressin receptor. Journal of Biological Chemistry 269 27088-27092.

Tajima T, Nakae J. Takekoshi Y, Takahashi Y, Yuri K, Nagashima T \& Fujieda K 1996 Three novel AVPR2 mutations in three Japanese families with $\mathrm{X}$-linked nephrogenic diabetes insipidus. Pediatric Research 39 522-526.

Thibonnier M, Goraya T \& Berti-Mattera L 1993 G protein coupling of human platelet V1 vascular vasopressin receptors. American Journal of Physiology 264 C1336-C1344.

Thibonnier M, Auzan C, Madhun Z, Wilkins P, Berti-Mattera L \& Clauser E 1994 Molecular cloning sequencing and functional expression of a cDNA encoding the human V1a vasopressin receptor. Journal of Biological Chemistry 269 3304-3310.

Trumpp-Kallmeyer S, Chini B, Mouillac B, Barberis C, Hoflack J \& Hibert M 1995 Towards understanding the role of the first extracellular loop for the binding of peptide hormones to G-protein coupled receptors. Pharmacentica Acta Helvetiae 70 255-262.

Ufer E, Postina R, Gorbulev V \& Fahrenholz F 1995 An extracellular residue determines the agonist specificity of $\mathrm{V} 2$ vasopressin receptors. FEBS Letters $\mathbf{3 6 2}$ 19-23.

Wess J 1996 Molecular biology of muscarinic acetylcholine receptors. Critical Reviews in Neurobiology 10 69-99.

Wess J, Nanavati S, Vogel Z \& Maggio R 1993 Functional role of proline and tryptophan residues highly conserved among $G$ protein-coupled rceptors studied by mutational analysis of the m3 muscarinic receptor. EMBO Journal 12 331-358.

Received 18 July 1997

Accepted 14 October 1997 